\title{
THE ROLE OF SQ3R STRATEGY ON MATHEMATICAL COMMUNICATION ABILITY AND SELF REGULATED LEARNING OF SEVENTH GRADE STUDENT
}

\author{
Barnas $^{1}$, Utari Sumarmo', Mumun Syaban ${ }^{3}$ \\ ${ }^{1,2,3}$ IKIP Siliwangi, Cimahi \\ 1․ㅡarnas3567@gmail.com, ${ }^{2} \underline{\text { utari.sumarmo@gmail.com, }}{ }^{3}$ mumunsyaban58@gmail.com
}

Received: Sep 14 ${ }^{\text {th }}$, 2018; Accepted: Sep 15 $5^{\text {th }}, 2018$

\begin{abstract}
The study was a pre-test -post test experimental control group design having a goal to examine the role of SQ3R strategy and mathematics prior ability (MPA) on students' mathematical communication ability (MCA) and self regulated learning (SRL). The study involved 68 seventh grade students, a mathematical communication test, a mathematical SRL scale, and a perception on SQ3R strategy scale. The study found that on MCA, its Gain, and on SRL students getting treatment by SQ3R strategy attained better grades than the grades of students taught by conventional teaching, but the grades of MCA were still at low level, and of SRL the grades were at medium level. The other findings, there was high association between MCA and SRL, and students performed high perception toward SQ3R strategy.
\end{abstract}

Keyword: mathematical communication, self regulated learning, SQ3R strategy, perception toward SQ3R

\begin{abstract}
Abstrak
Penelitian ini adalah suatu eksperimen berdisain pretest-postes dan kelompok kontrol bertujuan memeriksa peranan strategi SQ3R dan kemampuan matematik awal (KAM) terhadap kemampuan komunikasi matematik (KKM) dan kemandirian belajar siswa (KB). Penelitian melibatkan 68 siswa kelas-7, satu tes KKM, satu skala KB, dan satu skala persepsi terhadap strategi SQ3R. Penelitian menemukan dalam KKM, N Gain-nya, dan dan KB siswa yang memperoleh strategy SQ3R mencapai mutu yang lebih baik daripada mutu siswa yang mendapat pembelajaran konvensional, namun mutu kedua KKM masih tergolong rendah, dan mutu kedua KB tergolong sedang. Temuan lainnya lagi, terdapat asosiasi tinggi antara KKM dan KB dan siswa menunjukkan persepsi yang baik terhadap strategi SQ3R .
\end{abstract}

Katakunci: komunikasi matematik, kemandirian belajar, strategi SQ3R, persepsi terhadap strategi SQ3R

How to Cite: Barnas., Sumarmo, U., \& Syaban, M. (2018). The Role SQ3R Strategy on Mathematical Communication Ability and Self Regulated Learning of Seventh Grade Student. JIML, 1 (3), 248-255.

\section{INTRODUCTION}

Basically mathematical communication ability (MCA) was an important mathematics learning outcome should be developed on student high school. There were some reasons supported that statement among other was MCA was attached in the goal of mathematics teaching NCTM (2000) such as: To communicate ideas by using symbols, table, diagram, or other media for explaining a situation or a daily problem and solving it, and to compile a story problem from a given mathematical model. Beside that, the importance of improving student's MCA was relvant to the nature of 
mathematics as symbolic language Sumarmo (2013) cited Usiskin who said it possessed superiority than any language such as mathematics symbol that had consistent idea or meaning. Other reasons were proposed by some experts namely: a) MCA helped students to sharpen their ways of thinking, to organize and to construct their knowlege, to improve their problem solving and reasoning abilities, to enchange self efficacy, and to improve soscial skills by Asikin as cited in Hulukati(2015); b) Communication as a part of mathematics took a role as a tool for thinking, deriving conclusion, expressing ideas clearly, exactly, and accurately, on social activities namely in interaction between student and teacher, student and student, between student and teaching material.

Further, Sumarmo(2013) cited Elliot and Kenney who detailed some processes of MCA as follow: a) To express a mathematical situation or problem, or daily life situation into figures, diagram, or mathematical symbol or mathematical model; b) To explain a mathematical idea, situation, and relation by using real thing, figure, graph, algebraic expression, or his own language writtenly or orally; c) To compile a story based on presented figures, diagram, or mathematical model; d) To pose question about presented mathematical content. To observe those processes of MCA task, they ilustrated that MCA task constituted higher order thinking (HOT) in mathematics. Implication of that statement was that for excecuting MCA students should have a strong mathematical disposition such as high motivation, to work hard willingly, and able to manage self-learning. The strong disposition among other was self regulated learning (SRL). Some experts as cited in Sumarmo (2006), defined SRL differently but they had three similar components, namely: to design self-learning objective; to select strategy; to monitor and to evaluate cognitive and affective processess and to compare them to a certain standard.

Indonesia mathematics curriculum, 2013 suggested that hard skill dan soft skill mathematics such as MCA and SRL should be developed simultaneously. One of teaching approaches that complied with the afformentioned suggestion was: survey, question, read, recite, and review (SQ3R) strategy. According to Suyatno (2009) and Robinson (1941, cited in Supinah 2012), SQ3R strategy constituted teaching strategy that allowed students to improve their understanding and metacognitive thinking ability via reading learning material accurately and thoroughly. Further, Arends (2008) and Slavin (2005) improved SQ3R strategy became PQ4R strategy those were preview, question, read, reflect, recite, and review. In steps of SQ3R and PQ4R strategies, student were paid close attention to read learning material precisely, posed question and answered it, and review thoroughly. Beside SQ3R or PQ4R strategies, there was other variabel that might took a role on improving student's MCA and SRL. To consider the nature of mathematics namely as a systimatic and structured science, it implied that for solving MCA succesively student should have mastered prerequisite mathematics content of MCA as well. As implication of that statement, researchers believed that student's prior mathematics ability (PMA) would take a role on obtaining MCA.

Hendrayana (2015) and Tandaliling (2011) reported the advantages of PQ4R strategy than conventional teaching on obtaining student's MCA and SRL. Other studies reported that on MCA students getting treatment with innovative teaching approaches attained better grades than the grades of students taught by conventioanl teaching. Likewise, some studies found that students getting treatment with innovative teaching obtained higher grades on SRL than the grades of students taught by conventional teaching. Beside those findings, some studies also reported that PMA took positive role on obtaining student's grades of various mathematics abilities, which pointed out by the higher level of students' PMA the studies found the higher students'grades of various mathematics abilities. 
Those afformentioned arguments motivated reseachers to carry out a study having a goal to analyze role of SQ3R and PMA on student's MCA and SRL, and posed research questions as follow:

1. Were the grades of MCA and its normalized gain, and of grade of SRL of students getting treatment with SQ3R strategy better than the grades of students taught by conventional teaching based on entirely and on each level of PMA?

2. What were student's difficulties on solving MCA tasks?

3. Was there any association between MCA and SRL?

4. Were there any interaction between PMA and teaching approaches toward MCA and SRL?

5. What was ilustration of student's activities during the lesson?

What were student's believe on SQ3R strategy?

\section{METHOD}

This study is a pre test-post test experimental controll group design which having a goal to analyze the role of PMA and SQ3R strategy on students' MCA and SRL. The sample of this study were 68 seventh grade students from selected randomly two classes from five classess of a Yunior High School in Cirebon. The study involved an multiple choice PMA test, an essay MCA test, a SRL scale, and a perception on SQ3R strategy scale. The PMA test consisted of 20 items, the MCA test consisted of 5 items, and the SRL scale consisted of 30 statements in Likert's model. By using Hendriana and Sumarmo (2014) as reference it was obtained charactristic of MCA test as follow: reliability test was $\mathrm{r}=.84$; item validity $(\mathrm{t})$ were $.73 \delta \mathrm{t} \delta .89$; discriminat power (DP) were $.24 \delta \mathrm{DP}$ $\delta .62$, and difficulty index (DI) were $.24 \delta$ DI $\delta .41$; and reliability self confidence scale $r=.82$. In the following, we attached sample items of mathematical communication test, and sample of SRL scale.

\section{Sample item of mathematical communication test}

Given $\mathrm{ABC}$ with $\mathrm{AB}=24 \mathrm{~cm}$ and $\mathrm{AC}=\mathrm{BC}=20 \mathrm{~cm}$. Points $\mathrm{D}$ and $\mathrm{E}$ are midle points of $\mathrm{AB}$ and AC.

a. Skets that situation and draw with paralel lines area of ADE!

b. Compile mathematics model for calculating circumtance of ADE. Then solve it and write the rules used in each step of the calculation.

\section{Sample item of mathematical communication test}

Given $\mathrm{ABCD}$ is a right trapezium at $\mathrm{A}$ with $\mathrm{AB} / / \mathrm{DC}$. Points $\mathrm{P}$ and $\mathrm{Q}$ are two points in $\mathrm{BD}$, so that $\mathrm{P}$ and $\mathrm{Q}$ divides $\mathrm{BD}$ into three parts with $\mathrm{BP}=\mathrm{PQ}=\mathrm{QD}$.

a. Skets that situation clearly

b. Compose mathematics model for computing ratio of area of APCQ and area of ABCD. Then solve it and write the rules used in each step of the computation.

\section{Sample Items of SRL Scale}

Note: SA: Strongly Agree A : Agree

\author{
DA: Disagree \\ SDA: Strongly Disagree
}

Table 1. SRL Scale

\begin{tabular}{|c|c|c|c|c|c|}
\hline No. & Statement & SA & $\mathbf{A}$ & DA & SDA \\
\hline 1. & $\begin{array}{l}\text { I am still silent when I realize a difficulty on solving } \\
\text { area of a non-simple geometry shape. (-) }\end{array}$ & & & & \\
\hline 2. & $\begin{array}{l}\text { I try to pose my opinion when we discuss about four- } \\
\text { sided shape despite my statement was uncertain true } \\
(+)\end{array}$ & & & & \\
\hline 3. & $\begin{array}{l}\text { I am confused to select mathematics content should } \\
\text { be learned deeper }(-) \text {. }\end{array}$ & & & & \\
\hline 4. & $\begin{array}{l}\text { I try to design a certain learning target for helping me } \\
\text { to obtain good grade on mathematics examination }(+)\end{array}$ & & & & \\
\hline
\end{tabular}




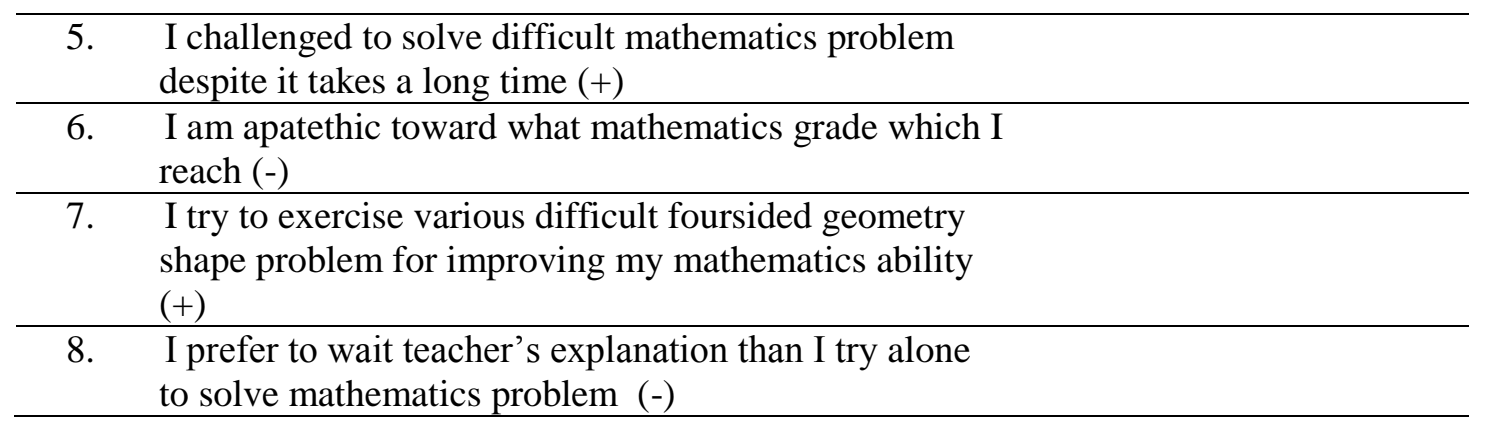

\section{Findings and Discussion}

Description of student's MCA and of student's SRL were attached in Table 1. Based on data in Table 1 , in pre-test it found that there was no difference of student's MCA grade in both teaching approaches, and the grades were at very low level. Nevertheles, after learning process, on MCA and its gain $(\mathrm{N}<\mathrm{G}>)$, students getting treatment with $\mathrm{SQ} 3 \mathrm{R}$ strategy attained better grades than the grades of students taught by conventional teaching, however both grades were at low level. Then, when we observed student's grades of MCA in each level of PMA in both teaching approaches, in post-test the higher level of student's PMA (low, medium, high) it found also the higher student's grades of MCA as well (in both teaching approaches were found $\overline{\mathrm{x}}_{\mathrm{L}}<\overline{\mathrm{x}}_{\mathrm{M}}<\overline{\mathrm{x}}_{\mathrm{H}}$ ). It meant that PMA took good role on obtaining student's MCA.

Likewise, in each level of PMA (low, medium, high), in post-test of MCA study found that $\overline{\mathrm{x}}_{\mathrm{SQ3R}}>$ $\overline{\mathrm{x}}_{\mathrm{CT}}$. It meant that SQ3R strategy took better role than conventional teaching on attaining student's MCA. Further, from Table 1, it found that student's MCA with low level of PMA in SQ3R strategy class (19.40) was higher than student's MCA with medium level of PMA in conventional class (18.12). But, student's MCA with medium level of PMA in SQ3R strategy class (24.71) was lower than student's MCA with high level of PMA in conventional teaching (26.33). Those findings ilustrated that SQ3R strategy and PMA had almost same level of role on attaining student's MCA. Similar findings were detected on the $\mathrm{N}<\mathrm{G}>$ of student's MCA. Those findings pointed out that level of PMA and SQ3R strategy took similar level of role on obtaining the MCA. However in this case, SQ3R strategy confered bigger role than PMA on attaining $\mathrm{N}<\mathrm{G}>$ of MCA.

Further, from Table 1, it was confered almost similar findings on student's SRL to findings on student's MCA. Those were level of PMA and SQ3R strategy took better role than conventional teaching on obtaining student's SRL. Moreover SQ3R strategy gave better role than PMA toward student's SRL. Testing hypothesis of $\overline{\mathrm{x}}_{\mathrm{SQBR}}>\overline{\mathrm{x}}_{\mathrm{CT}}$ on student's MCA, $\mathrm{N}<\mathrm{G}>\mathrm{MCA}$ and student's SRL in entirely students were attached in Table 2 .

Table 2. Description of Mathematical Communicationg Ability of Students in Both Teaching Approaches

\begin{tabular}{|c|c|c|c|c|c|c|c|c|c|c|}
\hline \multirow{2}{*}{$\begin{array}{l}\text { Vari- } \\
\text { able }\end{array}$} & \multirow{2}{*}{ PMA } & \multirow{2}{*}{$\begin{array}{c}\bar{x}, \% \\
, \mathrm{~s}\end{array}$} & \multicolumn{4}{|c|}{ SQ3R } & \multicolumn{4}{|c|}{ Conventional Teaching (CT) } \\
\hline & & & Pretes & Postes & $<G>$ & $\mathrm{N}$ & Pretes & Postes & $<G>$ & $\mathrm{n}$ \\
\hline & \multirow{3}{*}{ High } & $\overline{\mathrm{x}}$ & 13.71 & 33.71 & \multirow{2}{*}{.59} & \multirow{3}{*}{7} & 14.83 & 26.33 & \multirow{2}{*}{.34} & \multirow{3}{*}{6} \\
\hline & & $\%$ & 28.57 & 70.24 & & & 30.90 & 54.86 & & \\
\hline \multirow{5}{*}{ MCA } & & $\mathrm{s}$ & 3.15 & 4.99 & .13 & & 3.25 & 2.34 & .07 & \\
\hline & \multirow{3}{*}{ Medium } & $\overline{\mathrm{x}}$ & 10.82 & 24.71 & \multirow{2}{*}{.37} & \multirow{3}{*}{17} & 10.59 & 18.12 & \multirow{2}{*}{.20} & \multirow{3}{*}{17} \\
\hline & & $\%$ & 22.55 & 51.47 & & & 22.06 & 37.75 & & \\
\hline & & $\mathrm{s}$ & 2.92 & 4.67 & .16 & & 2.21 & 3.04 & .06 & \\
\hline & Low & $\overline{\mathrm{x}}$ & 6.40 & 19.40 & .31 & 10 & 6.91 & 13.45 & .16 & 11 \\
\hline
\end{tabular}


252 Barnas, Sumarmo \& Syaban, The Role SQ3R Strategy on Mathematical Communication Ability and Self Regulated Learning of Seventh Grade Student

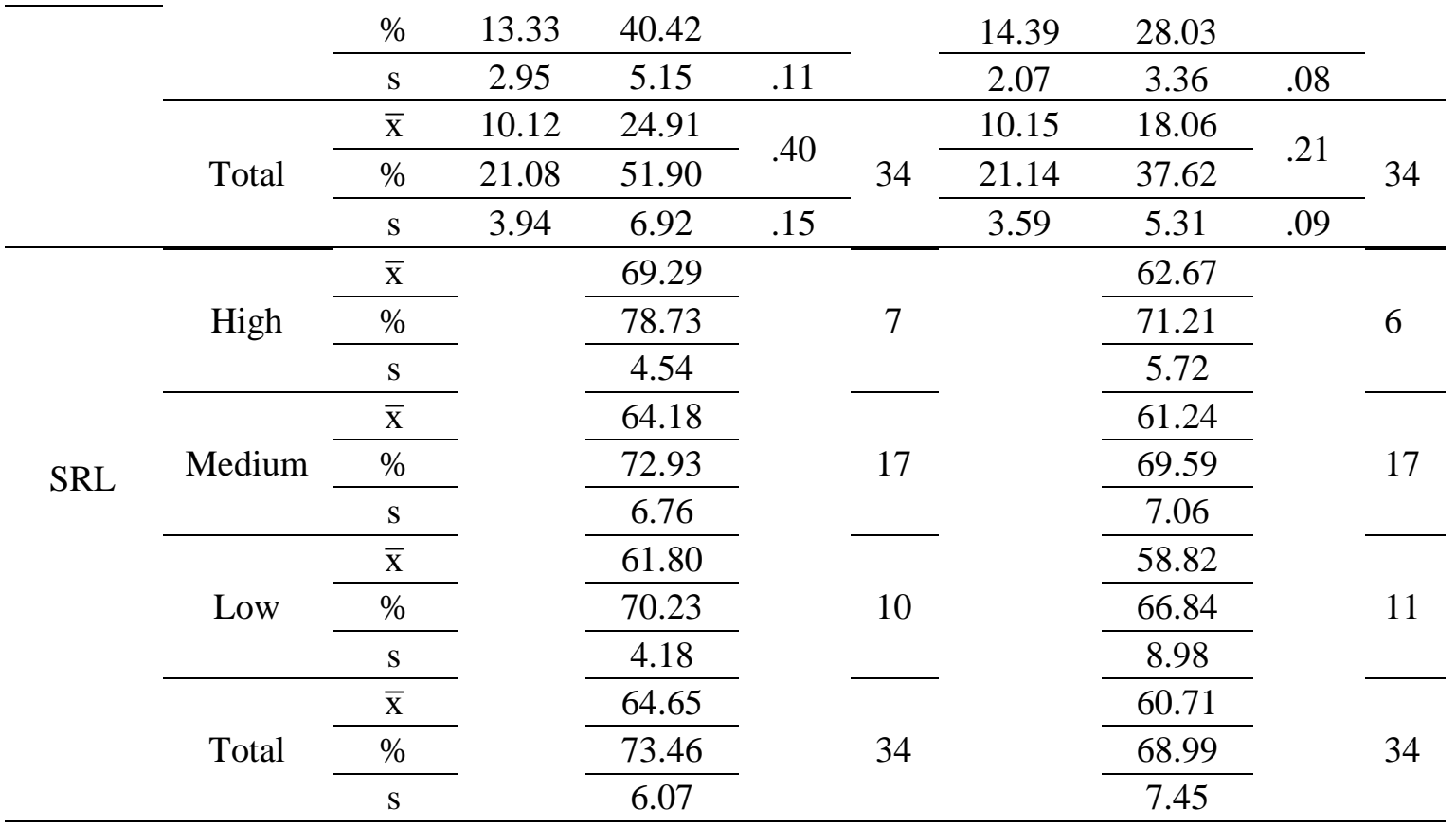

Ideal score of MCA is 48

Ideal score of SRL is 88

Based on Tabel 2 in entirely students, and in each level of PMA, the study found that student getting treatment with SQ3R obtained better grades of MCA and SRL than the grades of student taught by conventional teaching. However, student's grades of MCA were still at low level. These findings pointed out that students realized difficulty on solving MCA tasks. Students realized difficulties in solving problem about to compile mathematical model and to solve the of area of not simple geometry shape such as in Figure 1. This statement was supported by data on Table 3.

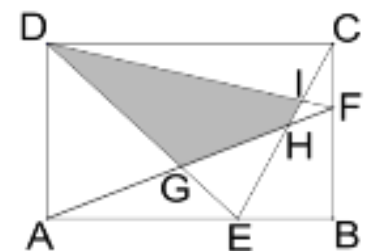

Figure 1. Geometry Shape
Observe Figure 1.

$\mathrm{ABCD}$ is a rectangular and area of AEG, BFHE, and CIF are $40 \mathrm{~cm}^{2}, 64 \mathrm{~cm}^{2}$ dan $9 \mathrm{~cm}^{2}$ successively. Formulate

Table 3.Testing Hypothesis of Mean Difference of MCA, N $<\mathrm{G}>$ MCA, and SRL on Both Teaching Approaches

\begin{tabular}{|c|c|c|c|c|c|c|c|}
\hline Variables & $\begin{array}{l}\text { Teaching } \\
\text { Approach }\end{array}$ & 目 & SD & $\mathrm{n}$ & $\begin{array}{l}\text { Sig (2- } \\
\text { tailed). }\end{array}$ & $\begin{array}{l}\text { Sig (1- } \\
\text { tailed). }\end{array}$ & Interpretation \\
\hline MCA & $\begin{array}{c}\text { SQ3R } \\
\text { CT }\end{array}$ & $\begin{array}{l}24.91 \\
18.06\end{array}$ & $\begin{array}{l}3.94 \\
5.31\end{array}$ & $\begin{array}{l}34 \\
34\end{array}$ & .00 & $.00<.05$ & $\begin{array}{l}\text { 国目 } \mathrm{MCA}_{\mathrm{SQ} 3 \mathrm{R}}> \\
\text { ? } \mathrm{MCA}_{\mathrm{CT}}\end{array}$ \\
\hline N-Gain & SQ3R & .40 & .15 & 34 & .00 & $.00<.05$ & 国回 N-GainMCA $\mathrm{SQ}_{\mathrm{SQR}}>$ \\
\hline MCA & CT & .21 & .09 & 34 & & & ? $\mathrm{N}-$ Gain $\mathrm{MCA}_{\mathrm{CT}}$ \\
\hline SRL & $\begin{array}{l}\text { SQ3R } \\
\text { CT }\end{array}$ & $\begin{array}{l}64.65 \\
60.71\end{array}$ & $\begin{array}{l}6.07 \\
7.45\end{array}$ & $\begin{array}{l}34 \\
34\end{array}$ & .020 & $.01<.05$ & $\begin{array}{l}\text { ? ? } \mathrm{SRL}_{\mathrm{Q} 3 \mathrm{R}}> \\
\text { ? of } \mathrm{SRL}_{\mathrm{CT}}\end{array}$ \\
\hline
\end{tabular}

Note: Mathematical Communication Ability Self Regulated Learning
Ideal score MCA: 48

Ideal score SRL : 88

Those findings were similar to the other findings of studies namely on MCA, students getting treatment with various innovative teaching obtained better grades than students taught by conventional teaching. Eventough, in those studies the students' grades of MCA were at medium-fairly good level. 
The students' difficulties on solving MCA task, was attached in Table 4. Students taught by SQ3R strategy attained medium score on three items, it pointed out students still realized a little bit difficluty on MCA task. Eventhough, most students taught by conventional teaching realized difficulties on all items of MCA. Seemingly, MCA tasks especially on compiling mathematics model and solving them on area and circumtance of non-simple geometry shape were difficult mathematical tasks for yunior high school students.

Table 4. Mean Score of Each Item of Mathematical Communication Ability of Students in The Both Teaching Approach

\begin{tabular}{ccccccc}
\hline $\begin{array}{c}\text { Teaching } \\
\text { approach }\end{array}$ & No & 1 & 2 & 3 & 4 & 5 \\
& Ideal score & 10 & 10 & 8 & 10 & 10 \\
\hline \multirow{2}{*}{ SQ3 } & \% of ideal score & 6.88 & 6.24 & 4.91 & 3.44 & 3.44 \\
& ? & 5.18 & 62 & 61.38 & 34 & 34.4 \\
CT & \% of ideal score & 51.8 & 44.7 & 3.12 & 2.35 & 3.00 \\
\hline
\end{tabular}

Further analysis, was concerning association between MCA and SRL. The association was analyzed by using contigency table such as in Table 4 and by using $\left.\right|^{2}$ testing. The analysis obtained value $P^{2}=$ 18.536 and sig. $(2$ tailed-.001 $<.005)$. This meant that there was high association $(\mathrm{C}=.707$ or $\mathrm{Q}=.866)$ between MCA and SRL.

Table 5. Contigency Table of Mathematical Communication Ability and Self Regulated Learning in SQ3R Class

\begin{tabular}{ccccc}
\hline SRL & MCA & Medium & Low & Total \\
\hline High & 3 & 14 & 0 & 17 \\
Medium & 0 & 0 & 17 & 17 \\
Total & 3 & 14 & 17 & 34 \\
\hline
\end{tabular}

Moreover, analysis on interaction between PMA and teaching approaches (SQ3R and CT) toward MCA and SRL were ilustrated on Table 5 and Table 6, and Figure 2 and Figure 3.

Table 6. Two Way Anova Between PMA and SQ3R Strategy and CT toward MCA

\begin{tabular}{cccccc}
\hline Sources & $\begin{array}{c}\text { Type III Sum of } \\
\text { Squares }\end{array}$ & df & $\begin{array}{c}\text { Mean } \\
\text { Square }\end{array}$ & F & \multirow{2}{*}{ Sig. } \\
\hline Teaching Aproaches & 617,660 & 1 & 617,660 & 38,994 & 0,000 \\
PMA & 1513,843 & 2 & 756,922 & 47,786 & 0,000 \\
Teaching Aproaches *PMA & 4,675 & 2 & 2,338 & 0,148 & 0,863 \\
\hline
\end{tabular}

Table 8. Two Way Anova Between PMA and SQ3R Strategy and CT toward SRL

\begin{tabular}{cccccc}
\hline Sources & $\begin{array}{c}\text { Type III Sum of } \\
\text { Squares }\end{array}$ & df & $\begin{array}{c}\text { Mean } \\
\text { Square }\end{array}$ & F & Sig. \\
\hline Teaching Aproaches & 261.129 & 1 & 261.129 & 5.919 & .018 \\
PMA & 273.482 & 2 & 136.741 & 3.100 & .052 \\
Teaching Aproaches *PMA & 34.400 & 2 & 17.200 & .390 & .679 \\
\hline
\end{tabular}




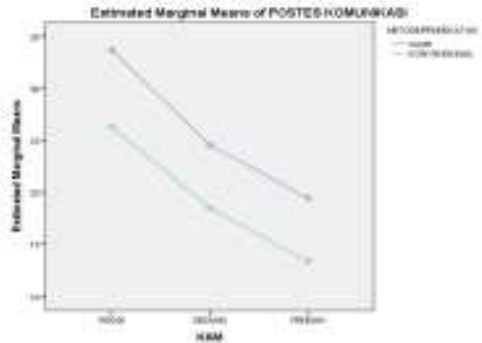

Figure 2. Interaction between PMA and Teaching Aproaches toward MCA

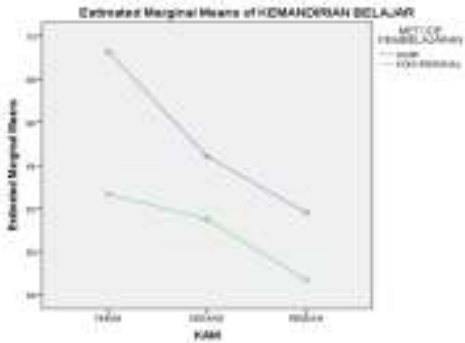

Figure 3. Interaction between PMA and Teaching Aproaches toward SRL

Result analysis on Table 7 and Table 8, Figure 2 and Figure 3, the study found that there were no interaction between PMA and teaching approaches (SQ3R and CT) toward MCA and SRL. These findings pointed out that SQ3R strategy took better role than PMA and CT on obtaining MCA and SRL.

Besides that, this study also found that students proposed positive opnion on SQ3R strategy and they performed active learning in all phases of SQ3R strategy such as in the following figures (Figure 4, Figure 5, Figure 6, Figure 7). The students' positive opnion on SQ3R strategy was similar to students' opinion to other new accepted innovative mathematics teaching approaches in some recent studies such as: to Problem Based Learning Hendriana, H., Johanto, T., Sumarmo, (2018), to contextual teaching, and to generative teaching Sumarni, C. and Sumarmo (2017)

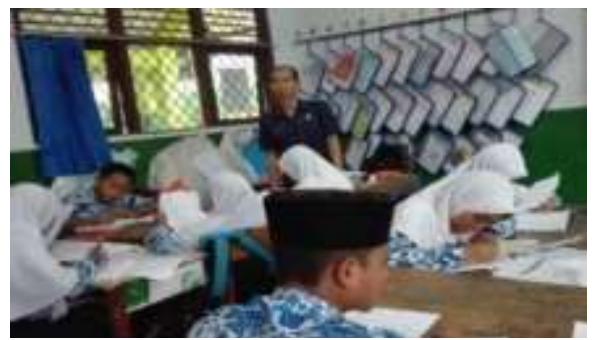

Figure 4. Students were active to identi

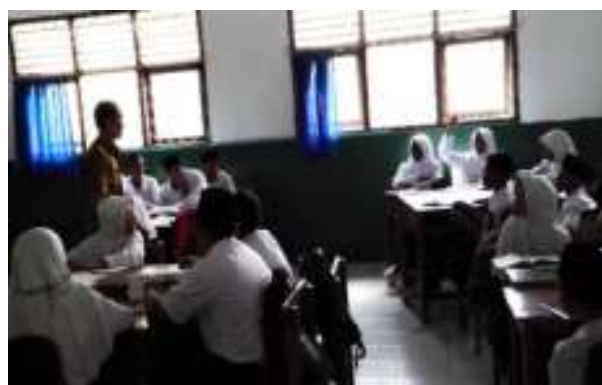

Figure 6 . Students ask question to teacher in question step

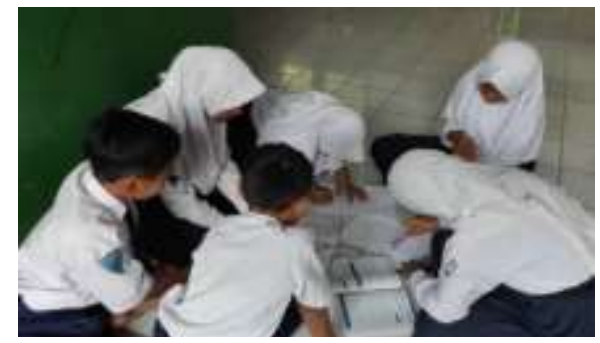

Figure 5. Students discuss to sellect relevant

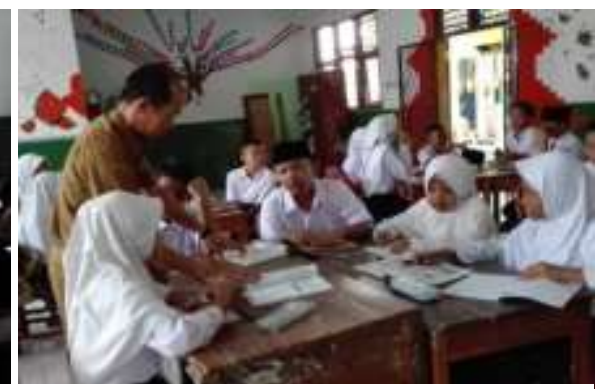

Figure 7. Students formulate mathematical model of the problem in question step

\section{Conclusion and Suggestion Conclusion}

Based on findings and discussion, the study derived conclusion as follow. Survey, Question, Read, Recite, Review (SQ3R) strategy took better role than conventional teaching on improving students' mathematical communication ability (MCA), its gain, and on students' Self Regulated Learning 
(SRL). However the students' MCA grades were still at medium level and while students' grades on SRL were at medium level. Likewise, level grade of PMA gave good role on obtaining student's grade on MCA, its NGain, and on SRL. Beside that, most students on conventional teaching realized difficulties in solving all MCA problems namely on formulating mathematical model and solving them about calculation of area and circumtances of non-simple geometry shape.

The other conclusion were that, students peformed active learning in all phases and posed positive opinion on SQ3R strategy, there was high association between MCA and SRL, and there was no interaction between PMA and teaching approaches (SQ3R and CT) on the grades of MCA and of SRL.

\section{Suggestion}

Based on the conclusion and discussion the study proposed some suggestion as follow.The students' grade on MCA in both class were at low level. It might be students needed more time for excersising problems of area non-simple geometry shape. Students should be motivated to select and to solve more exercises by theirselfes on mathematical communication tasks or on other non rutine mathematical problems. Further, in order students attained more meaningfull MCA, it was also suggested students asked to write the formulas and rules which used on each step in solving the problems as well.

To improve better students' SRL, it was suggested to follow Sauri's recomendation namely: Be aware of students to the importance of having SRL attitude; teacher should perform having behavior as wished in SRL; students should be accustomized having behavior as wished in SRL; and teacher should carry out integrated and continous mathematics teaching process.

\section{REFERENCES}

Arends, R. I. (2008). Learning to Teach: Belajar untuk Mengajar. Buku Dua. (Penterjemah: Helly Prayitno Soetjipto dan Sri Mulyantini Soetjipto). Yogyakarta: Pustaka Pelajar.

Hendrayana, E. (2015). Penerapan Strategi Pembelajaran PQ4R untuk Meningkatkan Kemampuan Pemahaman Dan Komunikasi Matematik Serta Kemandirian Belajar Siswa SMA. Bandung: Unpublished Theses at Postgraduate STKIP Siliwangi.

Hendriana, H., Johanto, T., Sumarmo, U. (2018). The Role of Problem Based Learning To Improve Student's Problem Solving Ability and Self Confident. Journal on Mathematics Education, 9(2).

Hulukati, E. (2015). Mengembangkan Kemampuan Komunikasi dan Pemecahan Masalah Matematika Siswa SMP Melalui Model Pembelajaran Generatif. Disertasi. [Online], http://repository.upi.edu,.

NCTM. (2000). Principles and Standards for School Mathematics. USA: NCTM.

Slavin, R. E. (2005). Cooperative Learning Teori Riset dan Praktik.

Sumarmo, U. (2006). Kemandirian belajar: Apa, mengapa dan bagaimana dikembangkan pada peserta didik" Paper presented at Seminar of Mathematics Education in Department of Mathematics, Faculty of Mathematics and Science, State University of Yogyakarta. Makalah dimuat dalam Sur. Bandung: Jurusan Pendidikan Matematika FPMIPA UPI.No Title.

Sumarmo, U. (2013). Kumpulan Makalah Berpikir dan Disposisi Matematik serta Pembelajarannya. Jurnal Pendidikan Matematika.

Sumarni, C. and Sumarmo, U. (2017). Penalaran Matematik dan Kemandirian Belajar: Eksperimen terhadap Siswa SMP melalui Pembelajaran Generatif. Edusentris Jurnal Ilmu Pendidikan Dan Pengajaran, 3(1).

Tandaliling, E. (2011). Peningkatan Pemahaman dan Komunikasi Matematis Serta Kemadirian Belajar Siswa Sekokah Menengah Atas Melalui Strategi PQ4R dan Bacaan Reputation Text. Bandung: Desertasi SPs UPI . Unpublished Disertation at Post Graduate Study Indonesia Unive. 